Article

\title{
Interactions between Virtual Spaces and Schools: A Collective Case Study
}

\author{
Juan Miguel Martínez Martínez *(D) and Antonio Tudela Sancho \\ Department of Social Science Education, University of Granada, 18010 Granada, Spain; atudela@ugr.es \\ * Correspondence: jmarz@ugr.es
}

Received: 13 November 2020; Accepted: 1 December 2020; Published: 2 December 2020

\begin{abstract}
Information and Communication Technologies (ICT) play an important role in the current educational panorama. Their presence in educational centers has increased in the last decade due to the constant development of educational policies focused on their inclusion in the classroom. However, the integration of ICT in educational spaces and practices has still not reach the levels desired by international organizations such as the OECD and UNESCO. The aim of this study is to understand the nature of the interaction between virtual spaces and school spaces, and how this interaction affects the development of students' learning processes. To this end, we follow an interpretive research methodology using a collective case study with four students from Spain. The results highlight the scarce integration of ICT into educational centers and teaching practices. However, virtual spaces play an important role in the development of other learning processes, such as informed learning, informal learning, and learning outside of the school context. In this work, we also provide a brief overview of changes in the current educational situation due to the COVID-19 pandemic.
\end{abstract}

Keywords: education; collective case study; informal learning; ICT

\section{Introduction}

Young people between 15 and 25 years of age are the most frequent users of the internet and electronic devices in Spain and Europe [1]. Some of the most common uses include checking email, looking up information online, downloading multimedia content, instant messaging, and general internet usage [1]. Other authors [2] observe that young peoples' habitual use of virtual platforms can be divided into two main categories: a social category and a psychological category. The social category refers to individual differences in the use of social media, as well as the motivations and identities of the users, while the psychological category encompasses aspects such as social capital and wellbeing. Bernal and Angulo [3] add a third category, which refers to the need to use social networks to perform every-day activities. In other words, young people mainly use virtual spaces to socialize with their peers and have fun [4] but also to study, shop, and perform other day-to-day tasks [5].

Multiple investigations have studied the benefits that technology offers young people [6]. Social media plays an important role in their social practices and in the construction of their identities and relationships [7]. A growing number of works have focused on the question of how young people create and use social capital [8-12]. "Social capital" refers to the resources available to people through their social interactions [13]. Via social media, students increase their social capital, stimulating the resources integrated into their social structure and activating them for specific purposes [9].

Other studies have researched the academic use of social media and technology and the potential of ICT to contribute to students' learning [14-19]. Goméz-Aguilar et al. [18] conclude that social media is rarely used for academic purposes among the studied population. Although young people are frequent consumers of internet and social media content, they do not typically use these platforms 
to perform academic tasks. However, the study shows that students express interest in using these platforms for academic purposes.

Another line of investigation has addressed whether or not informal learning occurs in digital spaces, among both young and adult users [9,20-22]. In his investigation regarding the use of the Facebook platform, Erjavec [9] establishes the existence of a link between social networks and academic learning. The students who participated in the study identified different ways in which they used Facebook to de-stress or obtain help regarding subjects related to school, the most frequent examples being the exchange of practical information and the organization of group projects. Bylieva et al. [20] demonstrate that online communication groups aid in the inclusion and participation of students and help students to collaborate effectively in teams.

Young people frequently use virtual spaces to search for information. Bruce [23] introduces the concept of informed learning, i.e., the use of information in order to learn [24]. Other studies have investigated how young people's learning processes develop outside of educational institutions and within virtual platforms, such as, for example, studies regarding expanded education [25].

Over the last decade, the introduction of ICT into educational centers has been intensified [26]. However, the extent to which schools are incorporating ICT into their daily practices remains unclear [27]. International organizations such as the OECD and UNESCO have emphasized the need to continue integrating technology into classrooms, as well as the importance of improving teacher education and training regarding the use of ICT for educational purposes $[28,29]$. The objective of this study is to better understand the nature of the interaction between virtual spaces and academic spaces, and to identify how this interaction affects students' learning processes in the current moment. To perform this investigation, we have carried out a case study with four teenage subjects. We also report several preliminary results suggesting how the COVID-19 pandemic is changing the current educational panorama.

\section{Materials and Methods}

We have selected an interpretive research methodology, specifically the case study [30], taking into account the findings of Planella [31] regarding the importance of hermeneutics in educational research. We perform a collective case study in order to form a collective interpretation of the subject [32].

\subsection{Participants}

Four adolescents, two males and two females, between 15 and 16 years of age, participated in our study. The selection of this age group is due to their extensive consumption of technology, as other works in the field have shown [1,7]. We also make note of other characteristics such as the participants' sex and level of social media usage (see Table 1). To classify the participants' level of social media usage, we adapt the schema used by Megías and Rodríguez [1]. "High usage" refers to daily use of social networks such as Twitter, Facebook, and Instagram, as well as possession of a smartphone with internet capabilities and compatibility with popular communication applications (e.g., WhatsApp). We refer to the category that the authors denominate "medium usage" as "low usage," which signifies the occasional use of the aforementioned social media platforms.

Table 1. Characteristics of case subjects.

\begin{tabular}{cccc}
\hline Case Number & Level of Social Media Use & Age & Sex \\
\hline Case 1 & High & 15 & Male \\
Case 2 & Low & 16 & Male \\
Case 3 & Low & 15 & Female \\
Case 4 & High & 15 & Female \\
\hline
\end{tabular}

Participants were chosen according to the characteristics above: sex, age, and level of social media usage. The final group was selected such that all participants were 15 to 16 years of age for the reasons 
mentioned above, but otherwise varied in gender and level of social media usage in order to present a diverse set of cases. The selection process was performed by a contact person who was acquainted with each subject and aided us in selecting each participant based on the given characteristics. The role of the contact person is to prepare an initial contact between the investigators, the participant, and the participant's immediate social circle. Through the contact person, we reached out to each participant and their family in order to explain the nature of the investigation and relevant ethical matters.

\subsection{Data Collection Techniques}

We employed two commonly-used tools in qualitative research: the in-depth interview and the observation [33], specifically observation conducted using virtual ethnography [34].

The in-depth interviews consisted of a series of distinct face-to-face encounters between the researcher and the participants, in which the researcher sought to understand the meaning that the participants assign to their practices in virtual spaces. The interviews followed a flexible and open logic, in which there was no formal exchange of questions and answers [35]. Rather, the interviews took the form of conversations in which we did not follow a strict script.

In total, we conducted 20 interviews (five per participant) lasting approximately 45 min each. The first four interviews for each participant were conducted at the end of 2018, and the fifth was conducted in 2020 after the outbreak of the COVID-19 pandemic. The interviews took place in the participants' houses, with the idea that this setting would help the participants feel more comfortable and allow the discussion to flow naturally. Each meeting was recorded using at least two recording devices in order to avoid the possibility of electronic errors, and subsequently each interview was transcribed from these recordings. Before carrying out the interviews, we designed an interview protocol based on the bibliography used in the theoretical framework, the research questions, and the research objectives. In the vein of Flick [33], we created a flexible and open interview script so that the most important subjects for each participant—in other words, the emic subjects [30] — could come up naturally during the course of each interview.

Furthermore, we employed virtual ethnography to determine the practices of the participants in technological spaces. We use virtual ethnography as a qualitative research methodology that adapts the principles of traditional ethnographic research for a digital context, in order to study the culture and practices of online groups. Virtual ethnography is a useful tool for analyzing these practices in terms of what is done, why it is done, and under what conditions the subject acts within the virtual space [34]. To this end, we observed the participants' behavior on Instagram and, to a lesser extent, WhatsApp, for 12 months. Their activity was recorded and compiled in a log using various content formats: audio, images, etc. This observation, and the corresponding analysis, was carried out after the second round of in-depth interviews were conducted and the participants' most-used virtual platforms were identified.

\subsection{Data Analysis}

The selection of the bibliography and the creation of a theoretical framework informed our subsequent analysis. The choice of these sources served as an initial filter that conditioned our analysis and guided our focus toward certain categories. Likewise, the organization of the information obtained from these sources formed the basis for a system of categories. The approach we used was deductive-inductive: in other words, we began by using previous studies to contextualize our investigation, then created our own theory based on these texts, following the Grounded Theory laid out by Glaser and Strauss [36].

Our category system was informed by the topics emphasized by the subjects during their interviews, using a cyclical method of data collection and analysis (see Figure 1). In other words, we began by carrying out interviews and conducting virtual ethnography via observation of the participants on social media; this information was then continuously collected and incorporated into our final system of categories (see Figure 2). The final set of categories used were the following: 
informal learning (academic and emotional), informed learning, and social capital. We also studied possible changes in the research context due to the COVID-19 pandemic. The collection and analysis of information constitute a continuous process carried out during the course of the investigation [36]. We also used the spiral system suggested by Miles and Huberman [37], as this system allows us to review and process the obtained information while simultaneously observing the participants' evolving discourses. This analysis was performed using the NVivo software. This program aided us in classifying the data and performing the category analysis.

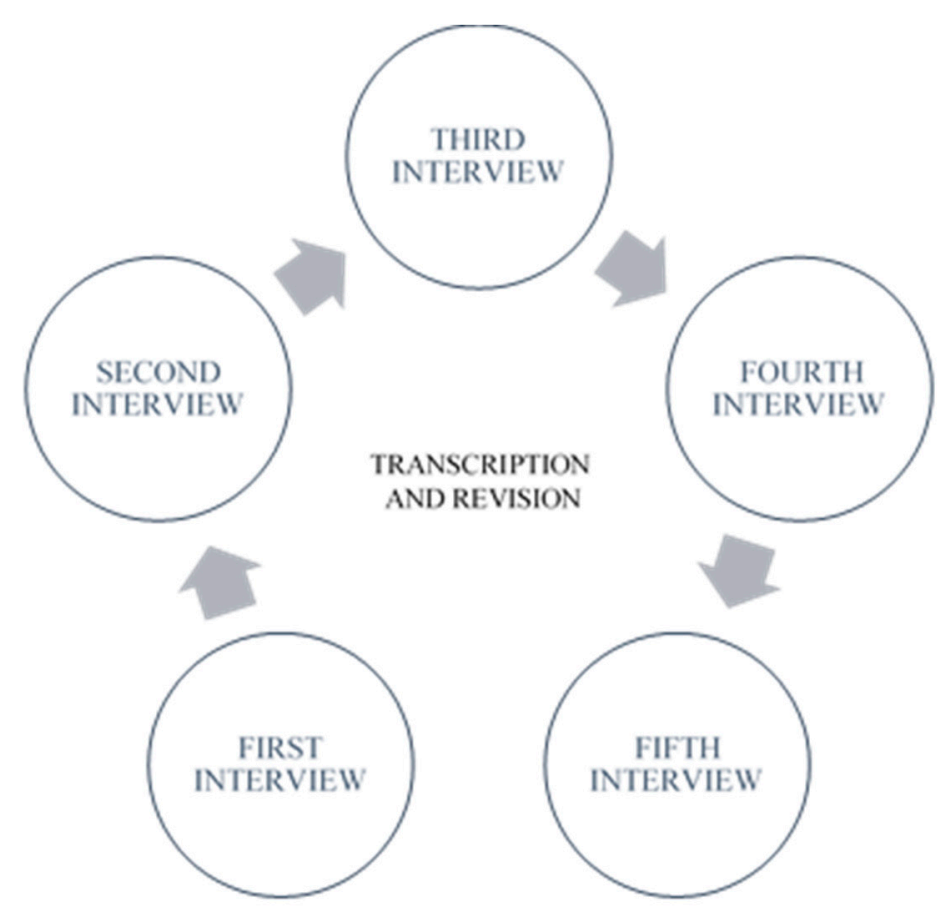

Figure 1. Cyclical method of data collection and analysis.

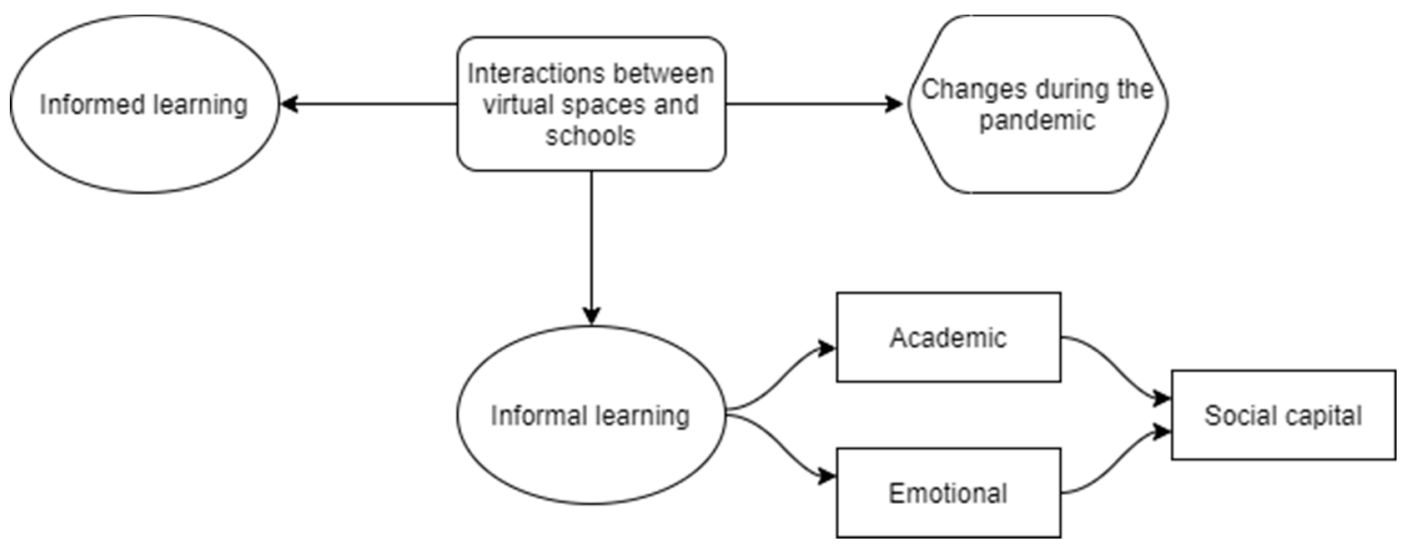

Figure 2. System of categories.

We define the selected categories as follows. The first category, informal learning, refers to all matters that support in-class learning. Within this category, we distinguish between "academic" and "emotional" subcategories. The "academic" subcategory refers to all interactions in which academic tasks have been resolved: for example, asking for the notes on a specific assignment. The "emotional" subcategory refers to all interactions that have provided emotional support to the participants: for example, discussing anxieties with a classmate. 
We also take into consideration the "social capital" category, which refers to participants' strategies for accumulating and mobilizing social capital: for example, searching for new friends on social networks. Furthermore, we sought to study the ways in which the participants use information obtained from virtual platforms to learn. This was done through the informed learning category, which encompasses all strategies that the participants use to carry out academic work, such as searching specific terms online for a class project. Finally, we took into account the impact that the COVID-19 pandemic has had on the general educational situation and learning practices of the participants.

In terms of the quality of the analysis, we use what Flick [38] refers to as the triangulation of researchers and triangulation of theories to formulate and finalize the category system. Two researchers have categorized the information and formulated a consensus on the category system together. Furthermore, all prior works included in the theoretical framework were definitive in configuring the final category system.

\subsection{Ethical Considerations}

We refer to the guidelines laid out by Flick [38] regarding important ethical considerations during this type of research:

- Informed consent: participants and their parents were required to sign a document informing them of the research objectives and other important aspects of the project, particularly those related to the participants' privacy and anonymity.

- Confidentiality: the reports are completely anonymous and contain no personally identifying information of any of the participants.

- Negotiation of the final report: the results reflected in the study were shown to the participants, who then consented to their publication, during the final interview.

\section{Results}

\subsection{Interactions between Schools and Virtual Spaces}

The use of virtual platforms within schools themselves was scarce. There was insufficient interaction between virtual spaces and school spaces, and when this interaction was present, it was marginal: "Bueno, Hotmail o Gmail principalmente, porque lo demás ... Los profesores suelen enviar los trabajos por ahí, nos los tenemos que descargar o a veces se los tenemos que enviar [Well, principally Hotmail or Gmail, because the others... The teachers usually send us assignments that way, and we have to download them or sometimes send them]" (Case 4, Interview 2). The participants typically used virtual platforms within their homes or elsewhere outside of school; within educational centers, the use of technology was effectively nonexistent.

Although technology was not used in the classrooms for learning purposes, it was frequently used outside of school for active purposes, i.e., informal learning. The participants use social media to discuss and resolve questions directly related to school. For example: "Sí, en plan: ¿tienes estos apuntes? ¿Tienes los ejercicios de matemáticas? Si no tengo libro pues lo pido [Yeah, do you have these notes? Do you have the math exercises? If I don't have the book I'll ask you for it]" (Case 3, Interview 1). This informal learning forms a source of emotional and academic support. The participants support one another to solve academic problems such as homework, obtaining materials, etc. They also communicate emotional support with their classmates on social media via private chats and class groups. It is important to highlight the role that social capital has in mobilizing these learning processes. The participants who had greater social capital generally had fewer difficulties in solving these problems, due to the fact that they had a larger number of friends and acquaintances who they could talk with to resolve their issues. Those participants who had greater social capital were also more likely to use this capital.

The participants also use social networks to learn outside of the school context. The most obvious example of this phenomenon, since our subjects did not use any specifically academic virtual platforms 
such as Massive Online Open Courses (MOOC), is their use of YouTube to view tutorials: "Sí, bueno, estoy enseñándome a hacer cosas con tutoriales, que hay muchos también [Yeah, I'm teaching myself to do things with tutorials, there are a lot of them]" (Case 1, Interview 1); "En aprender cosas, porque algunas personas tienen canal de YouTube y suben a Instagram que han hecho un tutorial o algo ... y ahí también puedes aprender cosas ... [To learn things, because some people have YouTube channels and they post on Instagram whenever they make a new tutorial or something ... and there you can learn things ... ]" (Case 3, Interview 5). In this case, the virtual platform grants young users the possibility to learn outside of formal educational spaces.

\subsection{Informed Learning}

One of the aspects studied during our investigation was the use of information for learning, a concept referred to by some authors as informed learning [23]. Of particular interest are the ways in which the participants used information to carry out academic tasks, and what learning processes were spawned as a result.

Several participants noted that they had never received effective instruction on how to search for and process information for academic tasks: "A mí, por ejemplo, en el colegio no me enseñaron a buscar información, pero a mi hermana pequeña sí que se lo enseñan ahora [For example, I was never taught in elementary school to search for information, but my little sister is learning it now]" (Case 1, Interview 2). This lack of preparation strongly influences the students' capacity to look up and process information, therefore limiting their ability to take advantage of technological resources for learning purposes.

In our analysis, we observe that, when it comes to looking up information, all participants follow a similar series of steps: they search their query online using Google, and from there they select one of the first results, almost always Wikipedia, which they use as a principal source and complement with another webpage. "Normalmente pongo las palabras clave de eso, y Wikipedia, y cuando ya has hecho un resumen o ya has hecho lo que necesitabas pues ya vas bajando las páginas [Normally I put in the keywords and start with Wikipedia, and when you've already written a summary or whatever you needed, you keep scrolling down the list of pages]" (Case 1, Interview 2).

Likewise, the treatment of information is similar in each case. The participants do not transform or process the information that they find online, but simply regurgitate it. There is no real "learning" occurring, since participants generally copy and paste the information without processing or analyzing it. As one participant summarized: "La reviso toda, la resumo y pillo lo más importante, lo principal que yo veo y lo pongo, alguna parte la copio, pero si yo sé algo del tema y veo que no está en esa información pues lo añado [I review all the information, I summarize it, I take the most important parts that I see and then I put those down, copying some parts, but if I know something about the topic and I see that the information is missing, I'll add it]" (Case 3, Interview 1).

\subsection{Changes during COVID-19}

The current situation has changed substantially due to the outbreak of the COVID-19 pandemic. The participants switched from in-person education to online/distance learning. They began using a virtual platform for all academic tasks, but they did not have live virtual classes. Within this virtual platform, the teachers uploaded homework assignments and the students downloaded them, then re-uploaded and submitted them once completed. The use of technology among educational actors has therefore increased substantially due to the unusual current situation. Nonetheless, technological tools have not been integrated into the teachers' methodology itself, but simply into their way of distributing and collecting assignments.

Informal learning has also increased during this period, due largely to problems associated with submitting assignments on the new virtual platform as well as the lack of in-person contact between students (which the students therefore supplement with virtual contact). The participants confirm that they have experienced greater levels of stress during this time period due to changes in the learning 
model. As a result, they have sought greater amounts of emotional support. The social capital of each participant was crucial in allowing them to solve academic problems, since communication with teachers has generally been poorer since the switch to online learning: "Con más de uno sí que no mantuvieron contacto en todos los meses de confinamiento [some students had no contact at all with teachers during the months of quarantine]" (Case 3, Interview 5).

Due to these circumstances, the participants maintained or increased their use of virtual spaces to learn outside the traditional classroom setting. This change may be due to participants spending more time exposed to virtual platforms, or an increased need to use these spaces for more purposes.

With regard to informal learning, the most notable change was that, since the teachers stopped using textbooks with the transition to online learning, the participants had to search for more information online. Therefore, their use of online information to perform academic tasks increased. The participants also obtained information from videos and documentaries that teachers assigned as mandatory viewing. The participants received no guidelines on how to search for information, despite the sudden lack of available explanations from lectures and textbooks.

\section{Discussion}

The aim of this study was to understand the nature of the relationship between virtual spaces and school spaces, and the effect of this relationship on the learning processes of high school students. The results of this study confirm that there is not a direct relationship between virtual spaces and schools. The participants do not directly use virtual platforms to perform academic tasks, and the internet is not typically used within the classroom, a finding consistent with other studies [18]. As such, the use of the internet and social media for academic reasons remains at the discretion of individual teachers [9].

As other authors do [27], we hypothesize that this finding is due primarily to lack of adequate teacher training regarding the use of ICT, as well as the limited technological infrastructure and educational resources available in schools. The results of our investigation highlight the fact that technology has not been effectively integrated into the classroom or into the practices of individual teachers. When students use technology, they do so in a superficial way, and the technology is not effectively integrated into the teaching methodology. This fact may present a problem when it comes to creating an effective educational methodology regarding the use of ICT in schools, as several international organizations such as the OECD [28] and UNESCO [29] have pointed out in their political agendas for 2030. Ghavifekr and Rosdy [15] find that training professors adequately in the use of ICT is a crucial factor in the success of technology-based learning.

Although our investigation does not find a direct link between virtual spaces and school spaces, the participants in our study frequently used virtual platforms to perform tasks related to school. Among these tasks, we differentiate between emotional support tasks, such as communicating with classmates online regarding anxieties and stresses related to school, and academic support tasks, such as asking classmates to virtually share notes or other class-related materials [9]. The participants who had greater social capital were more likely to use that capital to solve problems related to school. Communication among students was a fundamental contributor to their academic success and their ability to solve academic problems [20].

Our findings highlight the ways in which the participants use virtual platforms to develop learning processes outside of the classroom, a phenomenon studied in the literature on expanded education [25]. We have also observed the ways in which the participants use virtual platforms to search for information and use this information to learn. We find that participants have no education regarding how to find and process information effectively online, and they tend to copy or superficially summarize information obtained online without analyzing it in any deep way. For this reason, we emphasize the importance of creating and designing curricula based on informed learning [24]. 


\section{Conclusions}

In spite of the scarce interaction between virtual scenarios and school spaces, our investigation affirms the fact that social networks have educational value due to their infinite possibilities for information exchange and communication. The students who participated in our study frequently used virtual spaces to solve problems related to school and augment their social capital. Likewise, they developed learning processes outside of the school context by watching tutorials and looking up information online. Regarding this point, we show that students do not know how to effectively process the information they obtain online in order to learn, a topic we believe should be emphasized in educational institutions.

Based on our work, we make a naturalistic generalization, defined by Stake [30] as a process through which one gains insight by reflecting on an experience. Our primary objective was not this generalization, but rather transfer. In other words, we sought to understand each case in depth and, using this understanding, to extract useful information that can be applied to other cases with similar characteristics. We believe that the results presented in this work may be of use for analyzing and designing curricula that incorporate ICT.

The outbreak of the COVID-19 pandemic has necessitated the switch from in-person learning to digital learning, a change that has significantly altered the ways in which institutions, researchers, and teachers view education. It is important that educational policies evolve in order to promote the effective use of technology in the classroom and adapt schools to modern society. Along these lines, the 2030 agenda proposed by UNESCO has detailed the need to continue integrating ICT into educational institutions. UNESCO and the OECD have centered their attention on the importance of changing teaching methodologies to improve the performance of ICT in schools.

Future studies, with a greater number of participants and contexts, will provide a better general view of the interactions between virtual spaces and school spaces. These works should also investigate how the COVID-19 pandemic has affected the nature of these interactions and the educational situation in general. Further investigation on the topic will provide valuable insights on how to improve the integration of ICT into schools and into teachers' methodologies.

Author Contributions: Conceptualization, J.M.M.M. and A.T.S.; methodology, J.M.M.M. and A.T.S.; software, J.M.M.M.; formal analysis, J.M.M.M.; investigation, J.M.M.M.; writing—original draft preparation, J.M.M.M.; writing-review and editing, J.M.M.M. and A.T.S. All authors have read and agreed to the published version of the manuscript.

Funding: This research received no external funding.

Conflicts of Interest: The authors declare no conflict of interest.

\section{References}

1. Megías, I.; Rodríguez, E. Jóvenes y Comunicación: La Impronta de lo Virtual; Centro Reina Sofía Sobre Adolescencia y Juventud, FAD, Fundación de Ayuda Contra la Drogadicción: Madrid, Spain, 2014; ISBN 978-84-92454-24-2.

2. Colás-Bravo, P.; González-Ramírez, T.; De Pablos-Pons, J. Young People and Social Networks: Motivations and Preferred Uses. Comunicar 2013, 20, 15-23. [CrossRef]

3. Bernal, C.; Angulo, F. Interactions of Young Andalusian People inside Social Networks. Comunicar 2013, 20, 25-30. [CrossRef]

4. Muros, B.; Aragón, Y.; Bustos, A. La ocupación del tiempo libre de jóvenes en el uso de videojuegos y redes. Comunicar 2013, 20, 31-39.

5. Álvarez, I. Posibilidades Educativas de las Redes Sociales. Ph.D. Thesis, Universidade da Coruña, La Coruña, Spain, 2014.

6. Uhls, Y.T.; Ellison, N.B.; Subrahmanyam, K. Benefits and Costs of Social Media in Adolescence. Pediatrics 2017, 140, 67-70. [CrossRef]

7. Gangneux, J. Mediated Young Adulthood: Social Network Sites in the Neoliberal Era. Ph.D. Thesis, Univsersity of Glasgow, Glasgow, UK, 2018. 
8. Bye, L.; Muller, F.; Oprescu, F. The impact of social capital on student wellbeing and university life satisfaction: A semester-long repeated measures study. High. Educ. Res. Dev. 2020, 39, 898-912. [CrossRef]

9. Erjavec, K. Aprendizaje informal a través de Facebook entre alumnos eslovenos. Comun. Rev. Científica Iberoam. Comun. Educ. 2013, 21, 117-126.

10. Greenhow, C.; Burton, L. Help from My Friends: Social Capital in the Social Network Sites of Low-Income Students. J. Educ. Comput. Res. 2011, 45, 223-245. [CrossRef]

11. Valenzuela, S.; Park, N.; Kee, K.F. Is There Social Capital in a Social Network Site? Facebook Use and College Students' Life Satisfaction, Trust, and Participation1. J. Comput. Mediat. Commun. 2009, 14, 875-901. [CrossRef]

12. Steinfield, C.; Ellison, N.B.; Lampe, C. Social capital, self-esteem, and use of online social network sites: A longitudinal analysis. J. Appl. Dev. Psychol. 2008, 29, 434-445. [CrossRef]

13. Lin, N. Social Capital: A Theory of Social Structure and Action; Cambridge University Press: Cambridge, UK, 2002; ISBN 978-0-521-52167-3.

14. Bindu, C.N. Impact of ICT on teaching and learning: A literature review. Int. J. Manag. Commer. Innov. 2016, 4, 24-31.

15. Ghavifekr, S.; Rosdy, W.A.W. Teaching and Learning with Technology: Effectiveness of ICT Integration in Schools. Int. J. Res. Educ. Sci. 2015, 1, 175-191. [CrossRef]

16. Huang, Y.-T. Participatory Design to Enhance ICT Learning and Community Attachment: A Case Study in Rural Taiwan. Future Internet 2015, 7, 50-66. [CrossRef]

17. Den Exter, K.; Rowe, S.; Boyd, W.; Lloyd, D. Using Web 2.0 Technologies for Collaborative Learning in Distance Education-Case Studies from an Australian University. Future Internet 2012, 4, 216-237. [CrossRef]

18. Gómez, M.; Roses, S.; Farias, P. El uso académico de las redes sociales en universitarios, The Academic Use of Social Networks among University Students. Comun. Rev. Cient. Comun. Educ. Comun. Media Educ. Res. J. 2012, 19, 131-138. [CrossRef]

19. Wheeler, S. Learning Space Mashups: Combining Web 2.0 Tools to Create Collaborative and Reflective Learning Spaces. Future Internet 2009, 1, 3-13. [CrossRef]

20. Bylieva, D.; Bekirogullari, Z.; Kuznetsov, D.; Almazova, N.; Lobatyuk, V.; Rubtsova, A. Online Group Student Peer-Communication as an Element of Open Education. Future Internet 2020, 12, 143. [CrossRef]

21. Jin, B.; Kim, J.; Baumgartner, L.M. Informal Learning of Older Adults in Using Mobile Devices: A Review of the Literature. Adult Educ. Q. 2019, 69, 120-141. [CrossRef]

22. Greenhow, C.; Robelia, B. Informal learning and identity formation in online social networks. Learn. Media Technol. 2009, 34, 119-140. [CrossRef]

23. Bruce, C.S. Informed Learning; Association of College and Research Libraries/American Library Association: Chicago, IL, USA, 2008; ISBN 978-0-8389-8489-5.

24. Maybee, C.; Bruce, C.S.; Lupton, M.; Pang, M.F. Informed learning design: Teaching and learning through engagement with information. High. Educ. Res. Dev. 2019, 38, 579-593. [CrossRef]

25. Rodríguez, E.F.; Martínez, R.A. Aprendizajes invisibles en contextos de educación expandida. Retos y oportunidades en la sociedad hiperconectada. Profesorado. Rev. Currículum Form. Profr. 2015, 19, 1-16.

26. Moltó, O. Neoliberalism, education and the integration of ICT in schools. A critical reading. Technol. Pedagog. Educ. 2013, 23, 267-283. [CrossRef]

27. Fernández Cruz, F.J.; Fernández Díaz, M.J.; Rodríguez-Mantilla, J.M. El proceso de integración y uso pedagógico de las tic en los centros educativos madrileños. Educacion XX1 2018, 21, 395-416. [CrossRef]

28. OCDE Students. Computers and Learning: Making the Connection; OECD Publishing: Paris, France, 2015; ISBN 978-92-64-23955-5.

29. UNESCO Leveraging Information and Communication Technologies to Achieve the Post-2015 Education Goal 2015. Available online: https://static1.squarespace.com/static/5b99664675f9eea7a3ecee82/t/ 5c61868c652deaef62dde26e/1549895335805/report_qingdao_web.pdf (accessed on 2 December 2020).

30. Stake, R.E. Investigación con Estudio de Casos; Pedagogía (Ediciones Morata), 4th ed.; Morata: Madrid, Spain, 2007. ISBN 978-84-7112-422-7.

31. Planella, J. Pedagogía y hermenéutica: Más allá de los datos en la educación. Rev. Iberoam. Educ. 2005, 36, 1-11.

32. Simons, H. Estudio de Caso: Teoría y Práctica; Morata: Madrid, Spain, 2011; ISBN 84-7112-645-1. 
33. Flick, U. El Diseño de Investigación Cualitativa; Investigación Cualitativa; Morata: Madrid, Spain, 2014; ISBN 978-84-7112-806-5.

34. Hine, C. Etnografía Virtual; Editorial UOC: Barcelona, Spain, 2004; ISBN 84-9788-019-6.

35. Taylor, S.J.; Bogdan, R. Introducción a los Métodos Cualitativos de Investigación: La Búsqueda de Significados; Paidós: Barcelona, Spain, 1994; ISBN 978-84-7509-816-6.

36. Glaser, B.G.; Strauss, A.L. The Discovery of Grounded Theory: Strategies for Qualitative Research; Aldine: London, UK, 1967.

37. Miles, M.B.; Huberman, A.M. Qualitative Data Analysis: A Sourcebook of New Methods; Sage Publications: Beverly Hills, CA, USA, 1984.

38. Flick, U. La Gestión de la Calidad en Investigación Cualitativa; Investigación Cualitativa; Morata: Madrid, Spain, 2014; ISBN 978-84-7112-736-5.

Publisher's Note: MDPI stays neutral with regard to jurisdictional claims in published maps and institutional affiliations.

(C) 2020 by the authors. Licensee MDPI, Basel, Switzerland. This article is an open access article distributed under the terms and conditions of the Creative Commons Attribution (CC BY) license (http://creativecommons.org/licenses/by/4.0/). 